\title{
PENGARUH LIKUIDITAS, NON-DEBT TAX SHIELD, UKURAN PERUSAHAAN DAN PERTUMBUHAN PENJUALAN TERHADAP STRUKTUR MODAL
}

\author{
Ni Putu Intan Wulandari ${ }^{1}$ \\ Luh Gede Sri Artini ${ }^{2}$
}

\author{
${ }^{1,2}$ Fakultas Ekonomi dan Bisnis Universitas Udayana (Unud), Bali, Indonesia \\ email:wulandarintan10@gmail.com
}

\begin{abstract}
ABSTRAK
Tujuan dari peneliti ini adalah untuk menguji dan menjelaskan signifikansi pengaruh likuiditas, non-debt tax shield, ukuran perusahaan dan pertumbuhan penjualan terhadap struktur modal pada perusahaan sektor pertambangan di Bursa Efek Indonesia. Pada penelitian ini dari jumlah populasi sebanyak 43 perusahaan sektor pertambangan yang terdaftar di Bursa Efek Indonesia tahun 2013-2016 hanya 10 perusahaan dipilih menjadi sampel yang telah memenuhi persyaratan.. Hasil penelitian menunjukkan bahwa secara parsial likuiditas berpengaruh negatif signifikan terhadap struktur modal, non-debt tax shield berpengaruh tidak signifikan terhadap struktur modal, ukuran perusahaan berpengaruh positif signifikan terhadap struktur modal dan pertumbuhan penjualan berpengaruh positif signifikan terhadap struktur modal. Berdasarkan hasil tersebut, manajemen perlu memperhatikan faktor-faktor yang mempengaruhi struktur modal, khususnya likuiditas, ukuran perusahaan dan pertumbuhan penjualan karena faktor ini terbukti memiliki pengaruh yang signifikan, sehingga diharapkan mampu menciptakan struktur modal yang optimal agar tercapainya tujuan perusahaan yaitu meningkatkan kesejahteraan pemegang saham.
\end{abstract}

Kata Kunci:struktur modal, likuiditas, non-debt tax shield

\begin{abstract}
The aim of this researcher is to test and explain the significance of the effect of liquidity, non-debt tax shields, company size and sales growth on the capital structure of mining sector companies in the Indonesia Stock Exchange. In this study of the total population of 43 mining companies listed on the Indonesia Stock Exchange in 2013-2016 only 10 companies were selected as samples that met the requirements. The results showed that liquidity partially had a significant negative effect on the capital structure, non-debt tax shield has no significant effect on capital structure, firm size has a significant positive effect on capital structure and sales growth has a significant positive effect on capital structure. Based on these results, management needs to pay attention to the factors that influence the capital structure, especially liquidity, company size and sales growth because these factors have proven to have a significant effect, so it is expected to be able to create an optimal capital structure in order to achieve corporate objectives, namely to improve shareholder welfare.
\end{abstract}

Keywords: capital structure, liquidity, non-debt tax shield 


\section{PENDAHULUAN}

Di era globalisasi dan kemajuan teknologi yang terus berkembang, perusahaan dituntut untuk menjadi lebih baik dan unggul dari pesaingnya. Perusahaan mengupayakan berbagai cara untuk menjadi lebih baik sehingga dapat bersaing dengan perusahaan lain. Salah satu upaya yang dilakukan oleh perusahaan berkaitan dengan operasional perusahaan yaitu penentuan keputusan pendanaan yang dihadapi oleh manajer keuangan. Keputusan pendanaan merupakan hal yang sangat penting diambil oleh para manajer karena berkaitan dengan bagaimana membiayai keputusan investasi yang akan dilakukan perusahaan (Wiagustini, 2014:234).

Komposisi dalam pendanaan tersebut perlu dipertimbangkan dalam rangka meminimalisasi resiko yang mungkin dapat terjadi dan harus ditanggung sebagai akibat dari keputusan yang diambil. Komposisi atau struktur modal yang optimal dapat menekan biaya modal (cost of capital) yang pada akhirnya dapat meningkatkan tingkat pengembalian ekonomis dan nilai perusahaan. Pentingnya struktur modal bagi perusahaan karena memiliki pengaruh yang sangat besar terhadap keuangan perusahaan serta nilai perusahaan. Perusahaan yang menggunakan pendanaan melalui utang akan mengurangi biaya pajak dan dapat meningkatkan keuntungan dari perluasan ekspansi perusahaan, namun apabila perusahaan tidak dapat mengelola kebijakan utangnya dengan baik, maka perusahaan tersebut akan mengalami financial distress (kesulitan keuangan).

Struktur modal merupakan pembiayaan permanen perusahaan yang terdiri dari utang jangka panjang dan modal sendiri (Margaretha, 2014:305). Utang 
jangka pendek tidak diperhitungkan dalam struktur modal karena utang jenis ini umumnya bersifat spontan sedangkan utang jangka panjang bersifat tetap selama jangka waktu yang relatif panjang sehingga keberadannya perlu dipikirkan oleh para manajer keuangan. Struktur modal dalam penelitian ini diproksikan dengan Long Term Debt to Equity Ratio (LTDER).

Terdapat beberapa teori yang mendasari struktur modal perusahaan yaitu Balancing theories dan Pecking Order Theory. Balancing theories merupakan suatu kebijakan yang ditempuh oleh perusahaan untuk mencari dana tambahan dengan cara mencari pinjaman baik ke perbankan, leasing atau juga dengan menerbitkan obligasi (bonds).Myers and Majluf mengemukakan teori struktur modal yang didasarkan atas asimetri informasi. Teori tersebut disebut sebagai pecking order theory. Pecking order theory menjelaskan mengapa perusahaan menyukai internal financing daripada external financing. Jika perusahaan ingin menggunakan external financing, perusahaan akan memilih menggunakan hutang terlebih dahulu dan ekuitas akan jatuh sebagai alternatif paling akhir (Husnan, 2015:279).

Sektor pertambangan diperlukan biaya investasi yang sangat besar, berjangka panjang, sangat berisiko dan adanya ketidakpastian yang tinggi menjadikan masalah pendanaan sebagai masalah yang terkait dengan pengembangan perusahaan. Perusahaan sektor pertambangan juga membutuhkanmodalyangsangatbesaruntukmengadakanpenyelidikansumber daya alam dan pengembangan sektor pertambangan, sehingga banyak perusahaan pertambangan yang masuk ke pasar modal untuk memperoleh investasi dan 
memperkuat posisi keuangannya. Mengenai keputusan pendanaan pada sektor pertambangan, pemerintah telah mewajibkan perusahaan tambang di Indonesia membangun pabrik pengolahan dan pemurnian hasil tambang (smelter) yang memerlukan modal yang sangat besar.

Menindaklanjuti amanat Undang-Undang Nomor 4 Tahun 2009, pemerintah mengeluarkan Peraturan Pemerintah Nomor 1 Tahun 2014 tentang larangan bagi perusahaan tambang di Indonesia untuk mengekspor bahan tambang mentah mulai Januari 2014. Diadakannya proses pengolahan dan pemurnian biji mineral di dalam negeri diharapkan akan memberikan nilai tambah yang lebih untuk setiap jenis mineral. Karena dana yang diperlukan untuk pembangunan smelter cukup besar, untuk itu pemerintah menyarankan pengusaha pertambangan dapat mengajukan pinjaman dari perbank asing dan nasional.

Pembangunan smelter dilatar belakangi oleh produksi biji mentah(raw material) hasil pertambangan Indonesia yang selalu diekspor ke luar negeri, sedangkan pabrik pemurnian dan pengolahannya berada di negara tujuan ekspor dimana sangat dapat merugikan Indonesia, karena nilai raw material lebih rendah dibandingkan dengan material yang sudah diolah dengan kualitas yang lebih tinggi. Kondisi inilah yang membuat pemerintah merancang adanya tahap lanjutan terhadap hasil pertambangan sebelum diekspor keluar negeri. 


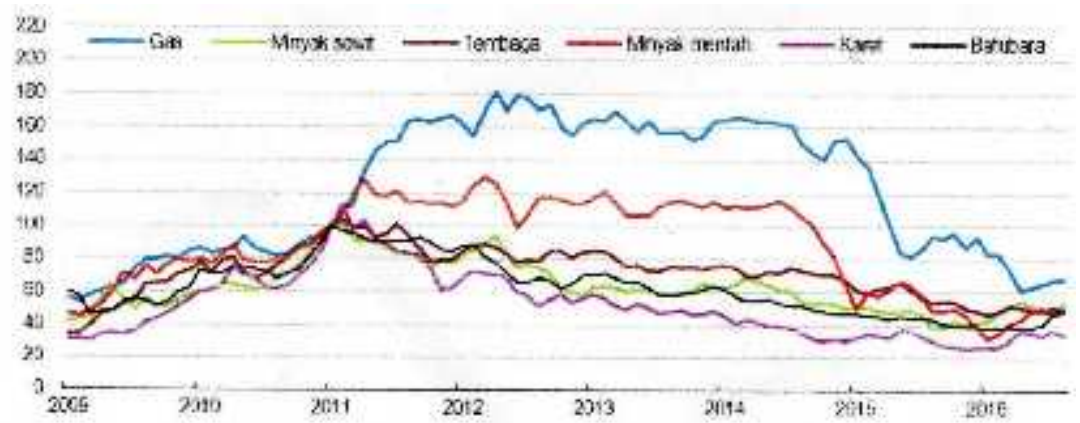

Gambar 1.Harga Komoditas Tertentu Tahun 2009-2016

Sumber: Basis Data IMF Commodity Price www.oecd.org

Berdasarkan grafik harga komoditas terlihat perusahaan sektorpertambangan mengalamipenurunandan memiliki pertumbuhan paling rendah sejak tahun 2013 sampai 2016. Penurunan dan pertumbuhan paling rendah terjadi karenaharga komoditas pertambangan dunia sedang mengalami penurunan harga mengikuti turunnya permintaan dari Tiongkok dan negara berkembang lainnya, serta adanya kebijakan Undang-Undang Mineral dan Batubara yang turut menekan pertumbuhan sektor pertambangan dari sisi internal.

\section{Tabel 1.}

Perkembangan Long Term Debt to Equity Ratio (LTDER) Perusahaan Pertambangan di BEI Tahun 2013-2016

\begin{tabular}{clrrrr}
\hline \multirow{2}{*}{ No } & \multicolumn{1}{c}{ Nama Perusahaan } & \multicolumn{3}{c}{ Long Term Debt to Equity Ratio (LTDER) } \\
\cline { 3 - 6 } & & \multicolumn{3}{c}{ Dalam Persentase } \\
\hline 1 & PT Radiant Utama Interinsco Tbk & 141,62 & 72,54 & 57,30 & 31,94 \\
2 & PT Citatah Tbk & 41,55 & 41,35 & 57,30 & 40,02 \\
3 & PT Aneka Tambang Tbk & 40,77 & 52,41 & 42,04 & 39,22 \\
4 & PT Cita Mineral Investindo Tbk & 25,77 & 24,46 & 43,55 & 110,35 \\
5 & PT Tambang Batubara Bukit Asam Tbk & 25,23 & 30,01 & 29,25 & 28,61 \\
6 & PT Elnusa Tbk & 23,00 & 11,01 & 12,29 & 2,05 \\
7 & PT Mitra Investindo Tbk & 18,11 & 11,31 & 18,69 & 25,05 \\
8 & PT Timah Tbk & 11,28 & 11,26 & 16,94 & 14,75 \\
9 & PT Bara Jaya International Tbk & 9,51 & 34,52 & 57,51 & 83,85 \\
10 & PT Perdana Karya Perkasa Tbk & 5,73 & 57,30 & 57,30 & 57,30 \\
\hline \multicolumn{2}{|l}{ Sumber: Data diolah, 2018 } & & & &
\end{tabular}

Berdasarkan tabel mengenai perkembangan long term debt to equity ratio perusahaan sektor pertambangan di BEI periode 2013-2016 mencerminkan 
beberapa perusahaan memiliki struktur modal yang tinggi lebih dari 100 persen. Struktur modal yang melebihi 100 persen menunjukkan perusahaan pertambangan tersebut menggunakan hutang lebih banyak daripada modal sendiri (equity). Selain itu investor cenderung lebih tertarik pada tingkat struktur modal tertentu yang besarnya kurang dari satu atau 100 persen.

Tabel perkembangan long term debt to equity perusahaan sektor pertambanganjuga menunjukkan perubahan struktur modal yang tidak konstan selama periode 2013 - 2016, artinya terjadi kondisi struktur modal naik dan turun (fluktuatif) sehingga terjadi perbedaan dan perubahan struktur modal dari waktu ke waktu antara perusahaan pertambangan yang satu dengan yang lainnya, maka diduga ada berbagai faktor yang mempengaruhi kebijakan manajemen mengenai struktur modal dan perlu dilakukan penelitian lebih lanjut mengenai faktor-faktor yang mempengaruhi struktur modal. Dengan mengetahui faktor-faktor yang mempengaruhi struktur modal, manajer perusahaan akan lebih mudah dalam mengambil keputusan pendanaan yang akan digunakan perusahaan untuk kegiatan operasional dan pengembangan usahanya.

Cara menentukan struktur modal yang optimal, perlu mempertimbangkan faktor-faktor penting yaitu tingkat penjualan, Struktur asset, Tingkat pertumbuhan perusahaan, Profitabilitas, Variabel laba dan perlindungan pajak, Skala perusahaan, Kondisi Internal perusahaan dan ekonomi makro (Sartono, 2014:248). Peneliti memilih menggunakan faktor internal perusahaan karena kondisi internal perusahaan sangat menentukan komposisi struktur modal perusahaan. Faktor internal perusahaan yang dapat mempengaruhi struktur modal 
menurut Chaklader dan Deepak (2016) adalah pertumbuhan penjualan, likuiditas, non-debt tax shield, aktiva berwujud dan ukuran perusahaan. Dari beberapa faktor atau variabel yang dapat mempengaruhi struktur modal, maka peneliti menggunakan empat faktor atau variabel pada perusahaan sektor pertambangan yaitu likuiditas, non-debt tax shield, ukuran perusahaan dan pertumbuhan penjualan. Penggunaan empat faktor tersebut juga dikarenakan masih terdapat perbedaan penelitian (research gap) pada penelitian terdahulu yang akan dibahas sebagai berikut.

Faktor pertama yaitu likuiditas yang merupakan kemampuan suatu perusahaan memenuhi kewajiban jangka pendeknya secara tepat waktu (Fahmi, 2016:65). Likuiditas perusahaan adalah kemampuan perusahaan dalam melunasi kewajiban jangka pendek yang telah jatuh tempo. Likuiditas merupakan perbandingan antara aktiva lancar dengan pasiva lancar. Jika perusahaan banyak menggunakan aktiva lancar, maka perusahaan tersebut dapat menghasilkan aliran kas untuk membiayai aktivitas operasi dan investasi perusahaan. Aktiva lancar yang semakin besar menunjukkan bahwa perusahan berhasil melunasi hutang jangka pendeknya, sehingga dapat berakibat pada menurunnya proporsi hutang dalam struktur modal.

Menurut pecking order theory, suatu perusahaan yang memiliki tingkat likuiditas yang tinggi akan cenderung mengurangi penggunaan hutang. Semakin tinggi tingkat likuiditas suatu perusahaan maka struktur modal perusahaan akan menjadi semakin rendah. Penelitian Abdulla (2017) dengan meneliti di perusahaan-perusahaan yang tidak terdaftar di Uni Emirat Arab (UAE) menyatakan 
bahwa likuiditas berpengaruh negatif terhadap struktur modal. Artinya semakin besar likuiditas yang dimiliki oleh perusahaan, maka semakin kecil dana eksternal khususnya utang yang digunakan perusahaan sehingga akan menurunkan struktur modal. Hasil ini konsisten dengan penelitian yang dilakukan oleh Alom (2013), Alipour et al. (2015), Shahar et al. (2016), Septiani dan Suaryana (2018) yang menyatakan bahwa likuiditas berpengaruh negatif terhadap struktur modal.

Hasil yang tidak konsisten atau berbeda pada penelitian yang dilakukan oleh Kartika dan Dana (2015) pada perusahaan Food and Beverages yang terdaftar di Bursa Efek Indonesia menyatakan bahwa likuiditas memiliki pengaruh positif dan signifikan terhadap struktur modal karena semakin tinggi likuiditas maka struktur modal akan semakin meningkat. Hasil penelitian tersebut konsisten dengan penelitian yang dilakukan oleh Adiyana dan Ardiana (2014), Primantara dan Rusmala (2016) serta Bhawa dan Rusmala (2015). Penelitian yang dilakukan oleh Nita dan Anam (2017) menyatakan bahwa likuiditas tidak berpengaruh terhadap struktur modal.

Faktor kedua dalam penelitian ini adalah non-debt tax shield merupakan faktor yang mempengaruhi struktur modal, terutama bagi perusahaan yang tidak ingin menggunakan hutang untuk menghindari resiko kebangkrutan. Non-debt tax shield adalah penghematan pajak sebagai akibat dari pembebanan depresiasi aktiva berwujud yang dapat mempengaruhi struktur modal perusahaan. Non-debt tax yang berupapembebanan biaya depresiasi dan amortisasi terhadap laba rugi. Depresiasi dan amortisasi berfungsi sebagai pendorong bagi perusahaan untuk mengurangi hutang karena depresiasi dan amortisasi merupakan cash flow sebagai 
sumber modal dari dalam perusahaan sehingga dapat mengurangi pendanaan dari hutang.

Potongan pajak (tax deduction) yang berupa depresiasi dan investment tax credit dapat digunakan untuk mengurangi pajak selain bunga hutang. Dalam melakukan efisiensi penghitungan pajak selain dengan membebankan biaya bunga hutang, perusahaan dapat memanfaatkan keuntungan atau perlindungan pajak melalui fasilitas perpajakan yang diberikan oleh pemerintah atau disebut dengan non-debt tax shield. Semakin besar penghematan pajak yang didapat dari non-debt tax shield maka semakin besar pula laba setelah pajak yang dapat digunakan untuk pendanaan perusahaan sehingga non-debt tax shield dapat dijadikan bahan pertimbangan bagi manajemen dalam menentukan struktur modal. Pecking order theory, menyatakan bahwa perusahaan dengan non-debt tax shields yangtinggi akan menurunkantingkat utang perusahaan jika keuntungan (laba) perusahaan meningkat karena sebagian keuntunganmerupakan sumber dana internal.

Hasil penelitian yang dilakukan oleh Bayrakdarogluet al. (2013) menyatakan bahwa Non-debt tax shield memiliki pengaruh positif signifikan terhadap struktur modal, karena perusahaan dengan aktiva tetap yang tinggi akan cenderung menggunakan utang lebih banyak dengan menggunakan aktiva tetap sebagai jaminan. Hasil konsisten dilakukan oleh Krisnanda dan Wiksuana (2015), Mahardika dan Aji (2017), serta Awan (2014) menyatakan non-debt tax shield memiliki pengaruh yang positif signifikan terhadap struktur modal.

Penelitian berbeda dilakukan oleh Dewi dan Dana (2017), non-debt tax shield memiliki pengaruh negatif signifikan terhadap struktur modal karena 
depresiasi yang tinggi menunjukkan perusahaan memiliki aset tetap yang tinggi, semakin tinggi aset tetap yang diinvestasikan maka jumlah depresiasi akan semakin tinggi dan semakin besar manfaat dari pengurangan pajak yang diterima, sehingga sumber dana internal yang dimiliki semakin besar yang berakibat pada rendahnya kebutuhan dana eksternal berupa utang. Pernyataan tersebut sejalan dengan penelitian lain yang dilakukan oleh Ariani dan Wiagustini (2017) serta Mouna and Hedi (2015). Hasil penelitian Sari dkk. (2013) menunjukkan bahwa non-debt tax shield tidak berpengaruh signifikan terhadap struktur modal, karena depresiasi tidak cukup bermakna sebagai pengurang pajak sehingga tidak diperhitungkan untuk mengurangi hutang dalam struktur modal.

Faktor ketiga adalah Ukuran perusahaan (Firm size) merupakan salah satu faktor yang dipertimbangkan perusahaan dalam menentukan berapa besar kebijakan keputusan pendanaan (struktur modal) dalam memenuhi ukuran atau besarnya aset perusahaan. Menurut Riyanto (2013:279) menyatakan bahwa besarnya suatu perusahaan juga mempengaruhi struktur modal perusahaan karena semakin besar suatu perusahaan akan cenderung menggunakan utang yang lebih besar. Perusahaan besar akan membutuhkan dana yang besar juga sehingga perusahaan yang memiliki ukuran perusahaan yang besar berpeluang untuk mendapatkan pinjaman dana berupa hutang jangka panjang, sehingga ukuran perusahaan yang besar dapat memperbesar struktur modal perusahaan. Perusahaan yang besar sering didevirsifikasikan lebih luas dan memiliki arus kas yang lebih stabil, sehingga kemungkinan pailit kecil dibandingkan perusahaan kecil (Kartika dan Dana, 2015). 
Ukuran perusahaan dilihat dari total aset yang dimiliki oleh perusahaan, yang digunakan untuk kegiatan operasi perusahaan, jika perusahaan memiliki total aset yang besar, pihak manajemen lebih leluasa dalam mempergunakan aset yang ada di perusahaan tersebut. Pecking Order Theory menyatakan perusahaan yang besar pastinya memiliki aset tinggi untuk menghasilkan laba, sehingga perusahaan dengan aset tinggi tidak memerlukan pinjaman berupa utang. Hasil penelitian didukung oleh Wardana dan Sudiartha (2015) pada Industri Pariwisata di Bursa Efek Indonesia menyatakan ukuran perusahaan berpengaruh negatif signifikan terhadap struktur modal. Hubungan negatif antara ukuran perusahaan dan struktur modal menunjukkan ukuran perusahaan mengalami peningkatan sehingga struktur modal perusahaan akan mengalami penurunan. Hasil ini konsisten dengan penelitian yang dilakukan oleh Alipouret al. (2015), Naibahodkk. (2015) serta Carnevela dan Wisyawati (2017).

Perbedaan hasil penelitian yang dilakukan oleh Alzomaia and Turki (2014) pada perusahaan yang listing di Saudi Arabia menyatakan bahwa terdapat hubungan yang positif antara ukuran perusahaan dengan leverage, meningkatnya ukuran perusahaan diikuti dengan peningkatan struktur modal karena ukuran perusahaan yang besar memberikan sinyal positif bagi pihak luar untuk memberikan tambahan modal sehingga struktur modal menjadi lebih besar. Hasil ini konsisten dengan penelitian yang dilakukan oleh Andawasatyaet al. (2017), Ismail dkk. (2015) dan Yousefzadehet al. (2014) yang mengatakan bahwa ukuran perusahaan berpengaruh positif dan signifikan terhadap struktur modal. Penelitian yang dilakukan oleh Sebayang dan Pasca (2013), Masnoon dan Abiha (2014), 
serta Babu dan G.V Chalam (2014) yang mendapatkan hasil ukuran perusahaan tidak berpengaruh signifikan terhadap strukturmodal.

Faktor terakhir adalah Pertumbuhan penjualan (growth of sales) yang merupakan selisih antara jumlah penjualan periode sekarang dengan periode sebelumnya dibandingkan dengan periode sebelumnya (Harahap, 2016:309). Tingkat pertumbuhan penjualan yang tinggi atau stabil dapat berdampak positif terhadap keuntungan perusahaan sehingga menjadi pertimbangan manajemen perusahaan dalam menentukan struktur modal. Penjualan yang stabil atau meningkat maka proyeksi laba yang diperoleh pun ikut stabil atau meningkat yang akan berpengaruh langsung terhadap besar kecilnya modal sendiri. Modal sendiri yang terdiri dari saham biasa atau laba ditahan akan semakin besar seiring dengan bertambahnya laba operasi perusahaan, dan akhirnya akan berdampak pada optimalisasi struktur modal perusahaan.

Hasil penelitian yang dilakukan oleh Saleemet al. (2013) yang meneliti pada perusahaan Oli dan Gas yang listing di Karachi Stock Exchange di Pakistan menemukan hasil bahwa pertumbuhan penjualan memiliki pengaruh yang negatif signifikan terhadap struktur modal karena semakin tinggi pertumbuhan penjualan perusahaan memiliki banyak pilihan dalam menggunakan sumber dana yang tidak beresiko sehingga lebih memilih pendanaan internal. Penelitian tersebut konsisten dengan penelitian lain seperti Yudiandari (2018), Nirmala dkk. (2016) serta Zuhria dan Ikhsan Budi Riharjo (2016).

Berbeda dengan penelitian yang dilakukan oleh Ariani dan Wiagustini (2017), perusahaan yang memiliki tingkat penjualan tinggi lebih memilih 
menggunakan utang, karena utang dapat digunakan perusahaan untuk melakukan ekspansi. Hasil penelitian ini konsisten dengan penelitian yang dilakukan oleh Umer (2014), Angelina dan Mustanda (2016), Erosvitha dan Wirawati (2016) serta Farisa dan Widarti (2017) menyatakan bahwa pertumbuhan penjualan berpengaruh positif dan signifikan terhadap struktur modal.Hasil penelitian yang dilakukan oleh Khariry dan Yusniar (2016), Zuliani dan Asyik (2014), serta Pradanadkk. (2013), yang menyatakan bahwa pertumbuhan penjualan tidak berpengaruh secara signifikan terhadap struktur modal.

Berdasarkan pecking order theory, tingkat likuiditas yang tinggi akan cenderung menahan perusahaan untuk menggunakan hutang karena perusahaan yang memiliki likuiditas yang tinggi berarti memiliki dana internal yang tinggi sehingga perusahaan tersebut akan mengutamakan penggunaan dana internal daripada menggunakan dana eksternal. Beberapa studi empiris mendukung pernyataan dari pecking order theory seperti penelitian Alom (2013), Widayantidkk. (2016), Juliantika dan Dewi (2016) serta Farrukh and Muzzafar (2017), menunjukkan bahwa likuiditas suatu perusahaan memiliki pengaruh negatif dan signifikan terhadap struktur modal. Berdasarkan uraian tersebut, maka hipotesis yang diajukan sebagai berikut:

$\mathrm{H}_{1}$ : Likuiditas berpengaruh negatif dan signifikan terhadap struktur modal Apabila non-debt tax shield perusahaan tinggi maka struktur modal perusahaan tersebut akan rendah, karena jumlah utang yang digunakan rendah. Teori tersebut konsisten dengan penelitian yang dilakukan Ariani dan Wiagustini (2017) menyatakan bahwa non-debt tax shield berpengaruh negatif dan signifikan 
terhadap struktur modal, tingginya depresiasi mencerminkan besarnya aset tetap yang dimiliki sehingga mendapatkan manfaat pajak dan pendanaan secara internal meningkat menyebabkan rendahnya kebutuhan dana eksternal berupa utang.Beberapa penelitian yang dilakukan Liem dkk (2013) dan Masidonda et al. (2013) menunjukkan bahwa non-debt tax shield berpengaruh secara negatif dan signifikan terhadap struktur modal. Berdasarkan kajian teori dan kajian empiris sebelumnya, maka dapat dirumuskan hipotesis sebagai berikut:

$\mathrm{H}_{2}$ : Non-debt tax shield berpengaruh negatif dan signifikan terhadap struktur modal

Putra dan Wijaya (2014) menemukan hubungan negatif pengaruh ukuran perusahaan terhadap struktur modal, karena ukuran perusahaan yang besar akan membuat struktur modal menjadi kecil. Persamaan hasil penelitian yang dilakukan oleh Liem dkk. (2013), Dewi dan Sudiartha (2017) serta Ariani dan Wiagustini (2017) yang menyatakan bahwa ukuran perusahaan berpengaruh negatif signifikan terhadap struktur modal.Berdasarkan kajian teori dan empiris maka hipotesis yang diajukan adalah sebagai berikut:

$\mathrm{H}_{3}$ : Ukuran Perusahaan berpengaruh negatif dan signifikan terhadap struktur modal.

Berdasarkan pecking order theory, perusahan dengan tingkat pertumbuhan penjualan yang tinggi cenderung membutuhkan dana tambahan dalam menjalankan kegiatan operasionalnya. Apabila perusahaan sudah tidak mampu mendanai kegiatan investasinya dari modal internal maka pilihan kedua yaitu menggunakan modal eksternal perusahaan yang berarti bahwa perusahaan dengan pertumbuhan penjualan yang tinggi akan membutuhkan dana tambahan yang berasal dari luar karena dari dalam sudah tidak mencukupi, sehingga pertumbuhan 
penjualan yang tinggi akan mempengaruhi tingkat utangnya. Menurut Putri dan Fadhlia (2014) menyatakan bahwa pertumbuhan penjualan berpengaruh positif signifikan terhadap struktur modal, karena pertumbuhan penjualan yang tinggi akan memberikan kepercayaan yang lebih dari investor untuk memberikan pinjamannya kepada perusahaan karena terlihat dari kinerja keuangan yang baik.Persamaan hasil penelitian yang dilakukan oleh Bayunitri (2014) dan Darsono (2017) yang menyatakan bahwa pertumbuhan penjualan berpengaruh positif signifikan terhadap struktur modal.Berdasarkan kajian teori dan empiris tersebut maka dapat dirumuskan hipotesis sebagai berikut:

$\mathrm{H}_{4}$ : Pertumbuhan penjualan berpengaruh positif dan signifikan terhadap struktur modal.

\section{METODE PENELITIAN}

Lokasi penelitian ini dilakukan di semua perusahaan dalam sektor pertambangan yang terdaftar di Bursa Efek Indonesia (BEI) periode 2013-2016 yang dapat diakses melalui situs resmi yaitu www.idx.co.id. Data yang digunakan adalah Laporan Keuangan Tahunan perusahaan pertambangan periode 2013-2016 yang terdapat di Bursa Efek Indonesia.

Long Term Debt to Equity Ratio dinyatakan dalam presentase dengan rumus sebagai berikut:

$$
L \quad T \quad D \quad \text { ti } E \quad R \quad=\frac{h u \quad \mu \quad p}{\text { Total Modal Sendiri }} x 100 \% \ldots .(1)
$$

Current Ratio dapat dirumuskan sebagai berikut:

$$
C \quad R \quad=\frac{A \quad L}{\text { Pasiva Lancar }} \times 100 \%
$$


NDTS dapat dirumuskan sebagai berikut:

$$
\mathrm{NDTS}=\frac{\mathrm{D}}{\mathrm{T} A \mathrm{~A}} \times 100 \%
$$

Ukuran perusahaan dirumuskan sebagai berikut:

Ukuran Perusahaan $=\operatorname{Ln}($ Total Aset $)$

Pertumbuhan penjualan pada penelitian ini yaitu perbandingan antara total penjualan periode sekarang (total sales t) dikurangi periode sebelumnya (total sales t-1) terhadap total penjualan di periode sebelumnya (total sales t-1) dari tahun 2013-2016 pada perusahaan sektor pertambangan di Bursa Efek Indonesia yang dinyatakan dalam persentase serta dapat dinyatakan dalam rumus sebagai berikut

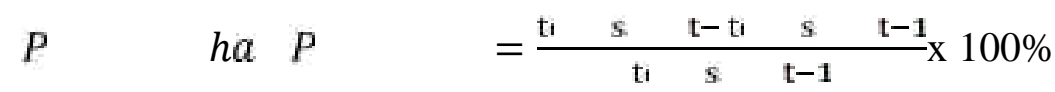

Analisis regresi linier berganda digunakan untuk mengetahui pengaruh dari variabel-variabel independen yaitu likuiditas $\left(\mathrm{X}_{1}\right)$, non-debt tax shield $\left(\mathrm{X}_{2}\right)$, ukuran perusahaan $\left(\mathrm{X}_{3}\right)$ dan pertumbuhan penjualan $\left(\mathrm{X}_{4}\right)$ terhadap variabel dependen yaitu struktur modal (Y). Data dalam penelitian ini akan dianalisis dengan uji statistik melalui bantuan software pengolahan data SPSS (Statistik Package for Social Sciense)versi23. Model regresi linear berganda yang dimaksud dirumuskan sebagai berikut (Utama, 2014:77):

$$
Y=\alpha+\beta_{1} X_{1}+\beta_{2} X_{2}+\beta_{3} X_{3}+\beta_{4} X_{4}+\varepsilon i
$$

Keterangan :

$\mathrm{Y}=$ Struktur Modal

$\alpha=$ Konstanta

$\beta_{1,2,3,4}=$ Koefisien Regresi masing-masing faktor

$\mathrm{X}_{1}=$ Likuiditas 
$\mathrm{X}_{2}=$ Non-debt Tax Shield

$\mathrm{X}_{3}=$ Ukuran Perusahaan

$\mathrm{X}_{4}=$ Pertumbuhan Penjualan

$\varepsilon \mathrm{i}=$ Standar error

Tabel 2.

Hasil Penentuan Sampel

\begin{tabular}{clc}
\hline No & \multicolumn{1}{c}{ Keterangan } & $\begin{array}{c}\text { Jumlah } \\
\text { Perusahaan }\end{array}$ \\
\hline 1. & $\begin{array}{l}\text { Perusahaan sektor pertambangan yang terdaftar di Bursa Efek } \\
\text { Indonesia periode 2013-2016 (populasi) }\end{array}$ & 43 \\
Perusahaan sektor pertambanganyang tidak menyediakan laporan \\
keuangan lengkap yang diperlukan dalam penelitian ini selama \\
periode 2013-2016.
\end{tabular}

\section{HASIL DAN PEMBAHASAN}

Hasil dari analisis regresi linier berganda dinyatakan pada Tabel 3.

Tabel 3.

Hasil Analisis Regresi Linier Berganda

\begin{tabular}{llc}
\hline \multicolumn{1}{c}{ Variabel } & Koefisien Regresi & Sig \\
\hline Likuiditas (X1) & $-0,288$ & 0,034 \\
NDTS (X2) & 0,249 & 0,067 \\
Ukuran Perusahaan (X3) & 0,400 & 0,003 \\
Pert. Penjualan (X4) & 0,291 & 0,026 \\
\hline R Square $=0,479$ & & $\mathrm{~F}=8,031$ \\
Adj. R Square $=0,419$ & & Sig $=0,000$ \\
\hline
\end{tabular}

Sumber: Data diolah, 2018

Berdasarkan Tabel 3 dapat dirumuskan persamaan regresi yang digunakan

dalam penelitian ini yaitu:

$Y=-0,288 X_{1}+0,249 X_{2}+0,400 X_{3}+0,291 X_{4}$

Keterangan:

$\mathrm{Y}=$ Struktur Modal

$\mathrm{X}_{1}=$ Likuiditas

$\mathrm{X}_{2}=$ Non-debt Tax Shield

$\mathrm{X}_{3}=$ Ukuran Perusahaan

$\mathrm{X}_{4}=$ Pertumbuhan Penjualan 
$\beta_{1}=-0,288$ menunjukkan bahwa apabila variabel likuiditas $\left(\mathrm{X}_{1}\right)$ naik sebesar 1 satuan maka struktur modal (Y) akan mengalami penurunan sebesar 0,288 dengan asumsi variabel bebas lainnya konstan. $\beta_{2}=0,249$ menunjukkan bahwa apabila variabel non-debt tax shield $\left(\mathrm{X}_{2}\right)$ naik sebesar 1 satuan maka struktur modal (Y) akan mengalami peningkatan sebesar 0,249 dengan asumsi variabel lainnya konstan. $\beta_{3}=0,400$ menunjukkan bahwa apabila variabel ukuran perusahaan $\left(\mathrm{X}_{3}\right)$ naik sebesar 1 satuan maka strukur modal $(\mathrm{Y})$ akan mengalami peningkatan sebesar 0,400 dengan asumsi variabel lainnya konstan. $\beta_{4}=0,291$ menunjukkan bahwa apabila variabel pertumbuhan penjualan $\left(\mathrm{X}_{4}\right)$ naik sebesar 1 satuan maka struktur modal (Y) akan mengalami peningkatan sebesar 0,291 dengan asumsi variabel lainnya konstan.

Koefisien determinasi $\left(\mathrm{R}^{2}\right)$ mengukur seberapa jauh variasi variabel terikat dapat dijelaskan oleh variabel bebas. Pada Tabel 3 memperlihatkan bahwa nilai $R$ Square sebesar 0,479 atau 47,9 persen. Hasil tersebut memiliki arti bahwa hanya 47,9 persen variasi dari variabel terikat yaitu struktur modal dapat dijelaskan oleh variasi variabel bebas yaitu likuiditas, non-debt tax shield, ukuran perusahaan dan pertumbuhan penjualan sedangkan sisanya 52,1 persen dijelaskan oleh faktor lain yang tidak dimasukkan dalam penelitian ini.

Hasil analisis kesesuaian model (Uji F) pada Tabel 3 menunjukkan bahwa besarnya nilai F hitung sebesar 8,031 dengan nilai Sig. sebesar 0,000. Nilai Sig F sebesar 0,000 yang lebih kecil dari tingkat signifikansi yaitu 0,05 memiliki arti bahwa variabel bebas likuiditas, non-debt tax shield, ukuran perusahaan dan 
pertumbuhan penjualan secara serempak berpengaruh terhadap variabel terikat yaitu sruktur modal.

Tabel 4.

Hasil Uji t

\begin{tabular}{|c|c|c|c|c|c|c|}
\hline \multirow{2}{*}{\multicolumn{2}{|c|}{ Model }} & \multicolumn{2}{|c|}{$\begin{array}{l}\text { Unstandardized } \\
\text { Coeficients }\end{array}$} & \multirow{3}{*}{$\begin{array}{c}\text { Standardized } \\
\text { Coefficients } \\
\text { B } \\
\end{array}$} & \multirow[b]{2}{*}{$\mathbf{t}$} & \multirow[b]{2}{*}{ Sig. } \\
\hline & & B & Std. Error & & & \\
\hline \multirow[t]{5}{*}{1} & (Constant) & $-5,520$ & 22,533 & & $-0,245$ & 0,808 \\
\hline & Likuiditas & $-0,126$ & 0,057 & $-0,288$ & $-2,206$ & 0,034 \\
\hline & NDTS & 3,094 & 1,636 & 0,249 & 1,891 & 0,067 \\
\hline & Ukuran Perusahaan & 2,312 & 0,734 & 0,400 & 3,151 & 0,003 \\
\hline & Pert. Penjualan & 0,015 & 0,007 & 0,291 & 2,322 & 0,026 \\
\hline
\end{tabular}

Berdasarkan Tabel 4 terlihat bahwa likuiditas memiliki nilai taraf signifikansi sebesar $0,034<\alpha=0,05$ yang berarti likuiditas mempunyai pengaruh yang signifikan. Nilai koefisien regresi sebesar -0,288 dengan tanda negatif yang memiliki arti bahwa secara parsial likuiditas memiliki pengaruh negatif signifikan terhadap struktur modal. Hipotesis 1 yang menyatakan likuiditas berpengaruh negatif signifikan terhadap struktur modal diterima.

Berdasarkan Tabel 4 menunjukkan bahwa non-debt tax shield memiliki nilai taraf signifikansi sebesar $0,067>\alpha=0,05$ yang berarti bahwa non-debt tax shield memiliki pengaruh tidak signifikan. Nilai koefisien regresi non-debt tax shield sebesar 0,249 dengan tanda positif yang memiliki arti bahwa secara parsial nondebt tax shield memiliki pengaruh tidak signifikan terhadap struktur modal. Hipotesis 2 yang menyatakan non-debt tax shield berpengaruh negatif signifikan terhadap struktur modal ditolak.

Berdasarkan Tabel 4 menunjukkan bahwa ukuran perusahaan memiliki nilai taraf signifikansi sebesar $0,003<\alpha=0,05$ yang berarti ukuran perusahaan memiliki pengaruh signifikan. Nilai koefisien regresi ukuran perusahaan sebesar 
0,400dengan tanda positif yang memiliki arti bahwa secara parsial ukuran perusahaan memiliki pengaruh positif signifikan terhadap struktur modal. Hipotesis 3 yang menyatakan ukuran perusahaan berpengaruh negatif signifikan terhadap struktur modal ditolak.

Berdasarkan Tabel 4 menunjukkan bahwa pertumbuhan penjualan memiliki nilai taraf signifikansi sebesar $0,026<\alpha=0,05$ yang berarti pertumbuhan penjualan memiliki pengaruh signifikan. Nilai koefisien regresi pertumbuhan penjualan sebesar0,291 dengan tanda positif yang memiliki arti bahwa pertumbuhan penjualan memiliki pengaruh positif dan signifikan terhadap struktur modal. Hipotesis 4 yang menyatakan pertumbuhan penjualan berpengaruh positif signifikan terhadap struktur modal diterima.

Likuiditas adalah kemampuan yang dimiliki oleh perusahaan untuk memenuhi kewajiban financial jangka pendeknya dengan dana lancar yang tersedia. Perusahaan dengan likuiditas yang tinggi berarti memiliki dana internal yang besar sehingga akan mengutamakan penggunaan dana internal daripada menggunakan dana eksternal berupa hutang.

Hasil penelitian menunjukkan bahwa likuiditas berpengaruh negatif signifikan terhadap struktur modal perusahaan sektor pertambangan di Bursa Efek Indonesia. Pengaruh likuiditas terhadap struktur modal yang menunjukkan arah negatif memiliki arti semakin besar likuiditas yang dimiliki perusahaan pertambangan maka semakin kecil dana eksternal khususnya utang yang digunakan perusahaan, sehingga akan menurunkan struktur modal. Beberapa perusahaan pertambangan di Bursa Efek Indonesia yang menjadi sampel dalam 
penelitian ini memiliki likuiditas yang kurang dari 100 persen, yang menunjukkan bahwa perusahaan tersebut masih memiliki likuiditas yang rendah yang mengindikasikan perusahaan tersebut memiliki dana internal yang rendah. Sesuai dengan pecking order theory yang menjelaskan bahwa perusahaan yang memiliki likuiditas tinggi akan cenderung tidak menggunakan pembiayaan dari utang, dikarenakan perusahaan dengan likuiditas yang tinggi mempunyai dana internal yang besar sehingga perusahaan tersebut akan lebih memilih menggunakan dana internalnya terlebih dahulu sebelum menggunakan pembiayaan eksternal. Hasil penelitian ini diperkuat dengan penelitian yang dilakukan oleh Pattwengkongka dan Napompech (2014), Juliantika dan Dewi (2016), Shintayani dan Panji (2015) serta Novitayanti (2018) yang menemukan bahwa likuiditas berpengaruh negatif signifikan terhadap struktur modal.

Hasil penelitian menunjukkan bahwa non - debt tax shield berpengaruh tidak signifikan terhadap struktur modal pada perusahaan sektor pertambangan di Bursa Efek Indonesia. Non- debt tax shield berpengaruhtidak signifikan terhadap struktur modal menunjukkan bahwa besar kecilnya non-debt tax shield yang menunjukkan besarnya pengurangan pajak akibat penggunaan selain hutang, yaitu depresiasi yang tidak mempengaruhi penggunaan hutang dalam struktur modal secara optimal dikarenakan besarnya depresiasi aset tetap yang dimiliki perusahaan. Dengan adanya ketidakpastian manfaat perlindungan pajak dan perusahaan sektor pertambangan memiliki aset tetap yang kecil sehingga non-debt tax shield yang dimiliki hanya kecil dan tidak diperhitungkan oleh perusahaan sebagai pengurang pajak. Hasil penelitian yang konsisten juga dilakukan oleh 
Saridkk. (2013), Pratheepan and Banda (2016) serta Prasetya dan Nadia (2014) menyatakan bahwa non - debt tax shieldberpengaruh tidak signifikan terhadap struktur modal.

Hasil penelitian menunjukkan bahwa ukuran perusahaan memiliki pengaruh positif signifikan terhadap struktur modal yang menunjukkan semakin besar ukuran perusahaan yang dimiliki perusahaan sektor pertambangan maka semakin besar pula dana eksternal khususnya utang yang digunakan perusahaan, sehingga akan meningkatkan struktur modal. Pengaruh positif ukuran perusahaan terhadap struktur modal dapat dijelaskan bahwa perusahaan besar akan mempunyai kesempatan yang luas dan mudah dalam memperoleh pinjaman, karena pihak kreditur lebih percaya untuk meminjamkan modal kepada perusahaan yang besar. Sehingga dapat dikatakan bahwa ukuran perusahaan dapat menjadi salah satu faktor yang mempengaruhi struktur modal karena semakin baik finansial perusahaan, maka dapat memberikan tingkat pengembalian yang mencukupi bagi pihak investor dan memberikan keyakinan pada investor bahwa perusahaan dapat memenuhi semua kewajibannya. Sehingga semakin tinggi ukuran perusahaan, maka semakin baik struktur modal perusahaan. Hasil penelitian yang konsisten juga dilakukan oleh Kartika dan Dana (2015), Ismail, dkk (2015) serta Ratri dan Ari (2017) yang menyatakan bahwa ukuran perusahaan memiliki pengaruh positif signifikan terhadap struktur modal.

Pertumbuhan penjualan adalah kenaikan jumlah penjualan dari tahun ke tahun atau dari waktu ke waktu. Perusahaan yang memiliki keuntungan yang meningkat dari penjualan, memiliki jumlah laba ditahan yang lebih besar. 
Peningkatan laba perusahaan meningkatkan jumlah modal sendiri yang berasal dari laba ditahan. Penjualan yang relatif stabil dan selalu meningkat pada sebuah perusahaan, memberikan kemudahan perusahaan tersebut dalam memperoleh aliran dana eksternal atau hutang untuk meningkatkan operasionalnya. Penjualan merupakan bagian yang memegang peranan penting dalam suatu perusahaan, karena hasil dari penjualan merupakan sumber utama kelangsungan usaha.

Hasil penelitian menunjukkan bahwa pertumbuhan penjualan memiliki pengaruh yang positif signifikan terhadap struktur modal perusahaan sektor pertambangan di Bursa Efek Indonesia. Nilai koefisien regresi yang positif menunjukkan bahwa meningkatnya pertumbuhan penjualan akan diikuti dengan meningkatnya struktur modal. Pertumbuhan penjualan yang tinggi akan menjadi salah satu pertimbangan bagi perusahaan dalam menentukan besarnya jumlah hutang yang akan digunakan. Semakin tinggi penjualan maka semakin tinggi keuntungan yang didapat oleh perusahaan, keuntungan yang didapat akan menjadi tambahan modal bagi perusahaan dalam melakukan pengembangan, sehingga peluang untuk menggunakan hutang akan semakin besar. Hasil penelitian ini didukung oleh Naibaho dkk. (2015), Putri dan Fadhlia (2015) serta Sawitri dan Lestari (2015) yang menyatakan bahwa pertumbuhan penjualan berpengaruh positif signifikan terhadap struktur modal.

\section{SIMPULAN DAN SARAN}

Likuiditas berpengaruh negatif signifikan terhadap struktur modal perusahaan sektor pertambangan di Bursa Efek Indonesia. Hasil tersebut memiliki arti apabila likuiditas mengalami peningkatan,maka struktur modal perusahaan 
akan mengalami penurunan.Non-debt tax shield berpengaruh tidak signifikan terhadap struktur modal. Hasil tersebut memiliki arti tinggi rendahnya non-debt tax shield tidak berpengaruh pada penentuan struktur modal perusahaan sektor pertambangan di Bursa Efek Indonesia.Ukuran perusahaan berpengaruh positif signifikan terhadap struktur modal perusahaan sector pertambngan di Bursa Efek Indonesia. Hasil tersebut menunjukkan bahwa semakin besar ukuran perusahaan yang dimiliki perusahaan sektor pertambangan maka semakin besar pula dana eksternal khususnya utang yang digunakan perusahaan, sehingga akan meningkatkan struktur modal.Pertumbuhan penjualan berpengaruh positif signifikan terhadap struktur modal perusahaan sektor pertambangan di Bursa Efek Indonesia. Hasil tersebut menunjukkan bahwa perusahaan dengan penjualan yang relatif tinggi berarti memiliki aliran kas yang relatif cepat maka dapat menggunakan utang lebih besar daripada perusahaan yang penjualan yang rendah.

Bagi perusahaan, penentuan struktur modal merupakan masalah penting bagi setiap perusahaan karena baik buruknya struktur modal akan mempunyai efek langsung terhadap posisi finansial perusahaan. Oleh karena itu sebaiknya manajemen perlu memperhatikan faktor-faktor yang mempengaruhi struktur modal khususnya, likuiditas, ukuran perusahaan, dan pertumbuhan penjualan.Bagi investor atau calon investor yang ingin menginvestasikan sahamnya pada suatu perusahaan sebaiknya melihat terlebih dahulu kondisi perusahaan apakah tepat untuk dipilih karena dalam hal ini investor harus menempatkan saham yang akan ditanamkannya pada perusahaan yang tepat. Untuk melihat kondisi perusahaan apakah tepat untuk dipilih yaitu dengan melihat 
Ni Putu Intan Wulandari, Pengaruh Likuiditas,Non...

kondisi laporan keuangan perusahaan diantaranya dengan melihat seberapa besar tingkat struktur modal yang digunakan.Bagi peneliti selanjutnya diharapkan menambah variabel lainnya sebagai variabel independen seperti risiko bisnis, profitabilitas, pajak serta kondisi ekonomi makro seperti tingkat suku bunga dan inflasi yang dapat mempengaruhi struktur modal perusahaan karena hasil penelitian menunjukkan kecilnya pengaruh variabel independen terhadap variabel dependen yang ditunjukkan dengan koefisien determinasi sebesar 47,9 persen dan sisanya 52,1 persen dipengaruhi oleh variabel lain di luar penelitian.Selain itu, peneliti selanjutnya juga diharapkan dapat melakukan penelitian pada sektor perusahaan lain yang terdaftar di Bursa Efek Indonesia dan menambah jumlah periode penelitian.

\section{REFERENSI}

Adiyana,Ida Bagus Gede Nicko Sabo dan Putu Agus Ardiana.(2014). Pengaruh Ukuran Perusahaan, Risiko Bisnis, Pertumbuhan Aset, Profitabilitas dan Likuiditas pada Struktur Modal. E-Jurnal AkuntansiUnud, 9 (3), 788-802.

Alipour, Mohammad, Mir Farhad Seddigh Mohhammadi dan Hojjatollah Derakhshan. (2015). Determinants of Capital Structure: An Empirical Study of Firms in Iran. International Journal of Law and Management, 57 (1), 5383.

Alom, Khairul.(2013). Capital Structure Choice of Bangladesh Firms: An Empirical Investigation. Asian Journal of Finance \& Accounting, 5 (1), 320333.

Alzomaia, Turki.(2014). Capital Structure Determinants Of Publicy Listed Companies In Saudi Arabia. The International Journal of Business and Finance Research, 8 (2), 53-67.

Andawasatya, Rizky, Nur Khusniyah Indrawati, dan Siti Aisjah. (2017). The Effect of Growth Opportunity, Profitability, Firm Size to Firm Value through Capital Structure (Study at Manufacturing Companies Listed On the Indonesian Stock Exchange). Imperial Journal of Interdisciplinary Research (IJIR), 3 (2), 1887-1894. 
Angelina, Kadek Irrine Devita dan I Ketut Mustanda.(2016).Pengaruh Ukuran Perusahaan, Pertumbuhan Penjualan dan Profitabilitas Pada Struktur Modal Perusahaan. E-Jurnal Manajemen Unud, 5 (3), 1772-1800.

Ariani, Ni Komang Ayu dan Ni Luh Putu Wiagustini.(2017). Faktor-Faktor yang mempengaruhi Struktur Modal Perusahaan Property dan Real Estate yang Terdaftar di BEI. E-Jurnal Manajemen Unud, 6 (6), 3168-3195.

Awan,Abdul Ghafoor.(2014). Determinants of Capital Structure. European Journal of Accounting Auditing and Finance Research, 2(9), 22-41.

Babu, Suresh dan G.V Chalam.(2014). Key Factors Influencing Capital Structure Decision of Indian Computer Software Industry. Indian Journal Of Applied Research, 4 (6), 103-105.

Bayrakdaroglu, Ali Ilhan Ege dan Nusret Yazici. (2013). A Panel Data Analysis of Capital Structure Determinants: Empirical Results from Turkish Capital Market. International Journal of Economics and Finance, 5 (4), 131-140.

Bhawa, Ida Bagus Made Dwija dan Made Rusmala Dewi. (2015). Pengaruh Ukuran Perusahaan, Likuiditas, Profitabilitas, Dan Risiko Bisnis Terhadap Struktur Modal Perusahaan Farmasi. E-Jurnal Manajemen Unud, 4 (7), 1949-1966.

Carnevela, Cindy Rosa dan Nurul Wisyawati. (2017). Pengaruh Pertumbuhan Penjualan, Ukuran Perusahaan dan Struktur Aktiva Terhadap Struktur Modal. Jurnal Ilmu dan Riset Manajemen, 6 (3), 2461-0593.

Chaklader, Barnali dan Deepak Chawla. (2016). A Study of Determinants of Capital Structure throught Panel Data Analysis of Firms Listed in NSE CNX 500. SAGE Publications, 20 (4), 267-277.

Darsono,Nurul Firmanullah. (2017). Faktor-Faktor Yang Mempengaruhi Struktur Modal di Perusahaan Indonesia (Pada Perusahaan Manufaktur yang Terdaftar di BEI Tahun 2011-2014). Diponogoro Journal of Accounting, 6 (3), 1-9.

Dewi, Dewa Ayu Intan Yoga Maha dan Gede Mertha Sudiartha. (2017). Pengaruh Profitabilitas, Ukuran Perusahaan, dan Pertumbuhan Aset Terhadap Struktur Modal dan Nilai Perusahaan.E-Jurnal Manajemen Unud, 6 (4), 2222-2252.

Dewi, Ni Kadek Tika Sukma dan I Made Dana. (2017). Pengaruh Growth Opportunity,Likuiditas,Non-Debt Tax Shield dan Fixed Asset Ratio terhadap Struktur Modal. E-Jurnal Manajemen Unud, 6 (2), 772-801.

Erosvitha, Cicilia Kadek Lia dan Ni Gusti Putu Wirawati.(2016).Pengaruh Profitabilitas,Set Kesempatan Investasi, Pertumbuhan Penjualan dan Risiko Bisnis pada Struktur Modal. E-Jurnal Akuntansi Unud, 14 (1), 172-197. 
Fahmi, Irham. (2016). Pengantar Manajemen Keuangan Teori dan Soal Jawab. Bandung: Alfabeta.

Farisa, Nurul Anggun dan Listyorini Wahyu Widati. (2017). Analisa Profitabilitas, Likuiditas, Pertumbuhan Penjualan, Struktur Aktiva dan Kebijakan Dividen terhadap Struktur Modal. Prosiding Seminar Nasional Multi Disiplin Ilmu dan Call For Papers Unibank ke-3, 9 (3), 640-649.

Farrukh, Wafa dan Muzaffar Asad.(2017). The Determinants of Capital Structure: A Study on Cement Sector of Pakistan. International Journal of Management Sciences and Business Research, 6 (2), 16-26.

Harahap, Sofyan Syafri. (2016). Analisis Kritis atas Laporan Keuangan. Jakarta: PT. Raja Grafindo Persada.

Husnan, Suad dan Enny Pudjiastuti. (2015). Dasar-dasar Manajemen Keuangan. Yogyakarta. Unit Penerbitan dan Percetakan (UPP STIM YKPN).

Ismail, Anas, Triyono dan Fathan Achyani. (2015). Faktor - Faktor Yang Mempengaruhi Struktur Modal Pada Perusahaan Property Dan Real Estate. Daya Saing Jurnal Ekonomi Manajemen Sumber Daya, 17 (1), 1-7.

Juliantika, Ni Luh Ayu Amanda Mas dan Made Rusmala Dewi.(2016). Pengaruh Profitabilitas, Ukuran Perusahaan, Likuiditas, dan Risiko Bisnis terhadap Struktur Modal Pada Perusahaan Property Dan Realestate. E-Jurnal Manajemen Unud, 5 (7), 4161- 4192.

Kartika, I Komang Sunarta dan Made Dana.(2015). Analisis Pengaruh Profitabilitas, Likuiditas, Ukuran Perusahaan, dan Tingkat Pertumbuhan terhadap Struktur Modal Perusahaan Food And Beverages yang Terdaftar di Bursa Efek Indonesia. E-Jurnal Manajemen Unud, 4 (3), 606-625.

Khariry, Mukhlan dan Meina WulansariYusniar. (2016). Faktor-Faktor Yang Mempengaruhi Struktur Modal (Studi kasus pada perusahaan Manufaktur yang terdaftar di Bursa Efek Indonesia periode 2011-2014. Jurnal wawasan Manajemen, 4 (2), 113-125.

Krisnanda, Putu Hary dan I Gusti Bagus Wiksuana.(2015).Pengaruh Ukuran Perusahaan,Pertumbuhan Penjualan dan Non-Debt Tax Shield terhadap Struktur Modal Pada Perusahaan Telekomunikasi Di Bursa Efek Indonesia. E-Jurnal Manajemen Unud, 4 (5), 1434-1451.

Liem, Jemmi Halim, Werner R. Murhadi dan Bherta Silvia Sutejo. (2013). FaktorFaktor yang Mempengaruhi Struktur Modal pada Industri Consumer Goods yang Terdaftar di BEI Periode 2007-2011. Jurnal Ilmiah Mahasiswa Universitas Surabaya, 2 (1), 1-11. 
Mahardika, I Putu Kresnayana dan Tony Seno Aji.(2017). Analisis Perbandingan Profitabilitas, Struktur Aset, Growth, Non-debt Tax Shield terhadap Struktur Modal Perusahaan (Studi pada Perusahaan yang Terdaftar dalam Main Board dan Development Board Tahun 2011-2015). Jurnal Ilmu Manajemen, 5 (3), $1-10$.

Margaretha, Farah. (2014). Dasar - dasar Manajemen Keuangan. Jakarta:PT Dian Rakyat.

Masidonda, Jaelani, M.S Idrus, Ubud Salim dan Djumahir. (2013). Determinants of Capital Structure and Impact Capital Structure on Firm Value. IOSR Journal of Business and Management, 7 (3), 23-30.

Masnoon, Maryam dan Abiha Saeed. (2014). Capital Structure Determinants Of Kse Listed Automobile Companies. European Scientific Journal. 10(13), 451-461.

Mouna, Zerria dan HediNoubbigh. (2015). Determinants of capital structure: evidence from tunisian listed firms. International Journal of Business and Management, 10 ( 9), 121-135.

Naibaho, Andreas,Topowijono dan Devi Farah Azizah.(2015). Pengaruh Profitabilitas, Pertumbuhan Penjualan, Struktur Aktiva dan Ukuran Perusahaan Terhadap Struktur Modal (Studi Kasus pada Perusahaan Property and Real Estate yang terdaftar di BEI tahun 2011-2013).Jurnal Administrasi Bisnis (JAB), 28 (1), 131-142.

Nirmala, Aulia, Moeljaadi dan Andarwati (2016). Pengaruh Ukuran Perusahaan, Profitabilitas, Pertumbuhan Penjualan dan Kepemilikan Manajerial terhadap Struktur Modal dan Nilai Perusahaan Manufaktur di Indonesia (Perspektif Pecking Order Theory). Jurnal Aplikasi Manajemen (JAM), 14 (3), 557-566.

Nita, Noviyanti dan Anam Hairul.(2017). Analisis Faktor-faktor yang Mempengaruhi Struktur Modal Perusahaan Sektor Pertambangan. Jurnal Sosial Humaniora dan Pendidikan, 1(1), 53-65.

Novitayanti, Cok Istri Diah dan Henny Rahyuda. (2018). Determinan Struktur Modal berdasarkan Pecking Order Theory pada Perusahaan Sektor Barang Konsumsi di BEI. E-Jurnal Manajemen Unud, 7(8), 4475-4507.

Pradana, Herdiawan Rudi, Fachrurrozie dan Kiswanto. (2013). Pengaruh Risiko Bisnis, Struktur Aset, Ukuran dan Pertumbuhan Penjualan terhadap Struktur Modal. Accounting Analysis Journal, 2(4), 1-10.

Prasetya, Bagus Tri dan Nadia Asandimitra. (2014). Pengaruh Profitabilitas, Ukuran Perusahaan, Growth Opportunity, Likuiditas, Struktur Aset, Resiko Bisnis dan Non Debt Tax Shield Terhadap Struktur Modal Pada Perusahaan Sub-Sektor Barang Konsumsi. Jurnal Ilmu Manajemen, 2 (4), 1341-1353. 
Pratheepan, Tharmalingam dan Y. K.Weerakoon Banda. (2016). The Determinants of Capital Structure: Evidence from Selected Listed Companies in Sri Lanka. International Journal of Economics and Finance, 8 (2), 94-106

Primantara, A.A Ngr Ag Ditya Yudi dan Made Rusmala Dewi. (2016). Pengaruh Likuiditas, Profitabilitas, Risiko Bisnis, Ukuran Perusahaan, dan Pajak Terhadap Struktur Modal. E-Jurnal Manajemen Unud, 5 (5), 2696-2726.

Putra, Dwi Ema dan I Ketut Wijaya Kesuma. (2014). Pengaruh Profitabilitas, Likuiditas, Ukuran, Pertumbuhan Terhadap Struktur Modal Industri Otomotif di BEI. E-Jurnal Manajemen Unud, 3 (4), 1753-1766.

Putri, Rachma Eka dan Wida Fadhlia. (2014). Pengaruh Struktur Aktiva dan Tingkat Pertumbuhan Penjualan terhadap Struktur Modal PerusahaanManufaktur yang Terdaftar di Bursa Efek Indonesia. Jurnal Dinamika Akuntansi dan Bisnis, 1 (2), 216-231.

Ratri, Anisa Mega dan Ari Christianti. (2017). Pengaruh Size, Likuiditas, Profitabilitas, Risiko Bisnis, dan Pertumbuhan Penjualan Terhadap Struktur Modal pada Sektor Industri Properti. JRMB, 12 (1), 13-24.

Riyanto, Bambang. (2013). Dasar-Dasar Pembelanjaan Perusahaan. (Edisi Keempat). BPFE UGM. Yogyakarta.

Saleem, Faiza., Bisma Rafique, Qaiser Mehmood, Muhammad Irfan, Rabian Saleem, Sidra Tariq, dan Ghazala Akram. (2013). The Determinant of Capital Structure of Oil and Gas Firms Listed on Karachi Stock Exchange In Pakistan. Interdisciplinary Journal of Contemporary Reaserch In Business 4(9), 225-235.

Sari, Dessy Handa, Atim Djazuli dan Siti Aisjah. (2013). Determinan Struktur Modal dan Dampaknya terhadap Nilai Perusahaan (Studi pada Perusahaan Makanan dan Minuman di Bursa Efek Indonesia). Jurnal Aplikasi Manajemen, 11 (1), 77-84.

Sartono, Agus R.(2014). Manajemen Keuangan Teori Dan Aplikasi. (Edisi Empat).Yogyakarta: BPFE.

Sawitri,Ni Putu Yuliana Ria dan Putu Vivi Lestari. (2015). Pengaruh Risiko bisnis,Ukuran perusahaan dan Pertumbuhan Penjualan terhadap Struktur Modal. E-Jurnal Manajemen Unud, 4 (5), 1238-125.

Sebayang, Minda., dan Pasca Dwi Putra. (2013). Pengaruh Karakteristik Perusahaan Terhadap Struktur Modal (Studi Empiris Pada Perusahaan Manufaktur Yang Terdaftar Di Bursa Efek Indonesia Periode 2006-2007). Jurnal Bina Akuntansi-IBBI, 19 (2), 1-10. 
Septiani, Ni Putu Nita dan I Gusti Ngurah Agung Suaryana.(2018.) Pengaruh Profitabilitas, Ukuran Perusahaan, Struktur Aset, Risiko Bisnis dan Likuiditas pada Struktur Modal. E-Jurnal Akuntansi Unud, 22 (3), 16821710 .

Shahar, Hanita Kadir, Azira Abdul Adzis dan Nureliana Baderi. (2016). The Relationship between Ownership Structure, Firm Specific Characteristics and Capital Structure: Evidence from Malaysian Middle-capital Public Listed Firms.International Journal of Economics and Financial Issues, 6 (3), 36-43.

Shintayani, Dian dan Ida Bagus Panji Sedana. (2015). Determinan Struktur Modal (Studi Komparatif pada Manufactur Multinational Corporation dan Domestic Corporation di BEI). E-Jurnal Manajemen Unud, 4 (10), 3375-3404.

Umer, UsmanMuhammed. (2014). Determinats of Capital Structure: Empirical Evidence from Large Taxpayer Share Companies in Ethiopia. Small International Journal of Economic and Finance, 6(1), 53-65.

Wardana, I Putu Arya Ditha dan Gede Mertha Sudiartha.(2015).Pengaruh Likuiditas,Ukuran Perusahaan, Risiko Bisnis dan Usia Perusahaan terhadap Struktur Modal pada Industri Pariwisata di Bursa Efek Indonesia Periode 2010-2013. E-Jurnal Manajemen Unud, 4 (6), 1701-1721.

Wiagustini, Ni Luh Putu. (2014). Dasar-dasar Manajemen Keuangan. Cetakan Pertama. Denpasar: Udayana University Press.

Widayanti, Luh Putu, Nyoman Triaryati dan Nyoman Abundanti.(2016). Pengaruh Profitabilitas, Tingkat Pertumbuhan Perusahaan, Likuiditas, dan Pajak Terhadap Struktur Modal Pada Sektor Pariwisata. E-Jurnal Manajemen Unud, 5 (6), 3761-3793.

Yousefzadeh, Nasrin, Zeinab Aazami, Hilda Shamsadini dan Mina Abousaiedi. (2014). Determinan Of Capital Structure Of Iranian Companies Listed In Tehran Stock Exchange: A Structural Equation Modeling Approach. Indian Journal of Commerce \& Management Studies, 5 (2), 1-20.

Yudiandari,Cokorda Istri Diah. (2018). Pengaruh Profitabilitas,Operating Leverage, Ukuran Perusahaan dan Pertumbuhan Penjualan pada Struktur Modal. E-Jurnal Akuntansi Unud, 22 (1), 408-437.

Zuhria, Siti Fatimatul dan Ikhsan Budi Riharjo. (2016). Pengaruh Profitabilitas, Free Cash Flow, Pertumbuhan Penjualan, Ukuran Perusahaan Terhadap Kebijakan Hutang. Jurnal Ilmu dan Riset Akuntansi, 5 (11), 1-21. 
Ni Putu Intan Wulandari, Pengaruh Likuiditas,Non...

Zuliani, Selly dan Asyik Nur Fadjrik. (2014). Pengaruh Profitabilitas, Pertumbuhan Penjualan, Struktur Aset dan Tingkat Pertumbuhan Terhadap Struktur Modal. Jurnal Ilmu dan Riset Akuntansi, 3 (7), 1-12. 